\title{
Connexins Are Critical for Normal Myelination in the CNS
}

\author{
Daniela M. Menichella, ${ }^{1,4}$ Daniel A. Goodenough, ${ }^{2}$ Erich Sirkowski, ${ }^{3}$ Steven S. Scherer, ${ }^{3}$ and David L. Paul ${ }^{1}$ \\ Departments of ${ }^{1}$ Neurobiology and ${ }^{2}$ Cell Biology, Harvard Medical School, Boston, Massachusetts 02115 , ${ }^{3}$ Department of Neurology, The University of \\ Pennsylvania Medical Center, Philadelphia, Pennsylvania 19104, and ${ }^{4}$ Institute of Neurology, Instituto di Ricovero e Cura a Carattere Scientifico Ospedale \\ Maggiore, Centro Dino Ferrari, University of Milan, Milan, Italy
}

\begin{abstract}
Mutations in Cx32, a gap-junction channel-forming protein, result in X-linked Charcot-Marie-Tooth disease, a demyelinating disease of the peripheral nervous system. However, although oligodendrocytes express $\mathrm{Cx} 32$, central myelination is unaffected. To explore this discrepancy, we searched for additional oligodendrocyte connexins. We found $\mathrm{Cx} 47$, which is expressed specifically in oligodendrocytes, regulated in parallel with myelin genes and partially colocalized with $\mathrm{Cx} 32$ in oligodendrocytes. Mice lacking either $\mathrm{Cx} 47$ or $\mathrm{Cx} 32$ are viable. However, animals lacking both connexins die by postnatal week 6 from profound abnormalities in central myelin, characterized by thin or absent myelin sheaths, vacuolation, enlarged periaxonal collars, oligodendrocyte cell death, and axonal loss. These data provide the first evidence that gap-junction communication is crucial for normal central myelination.
\end{abstract}

Key words: gap junction; connexin; myelin; oligodendrocyte; $\mathrm{Cx} 47$; $\mathrm{Cx} 32$

\section{Introduction}

Myelin sheaths are a fundamental adaptation of vertebrates. Although the structural components of myelin have been well characterized, the molecular mechanisms regulating the formation and maintenance of myelin are less well understood. In that regard, it is noteworthy that mutations in the gene encoding connexin32 (Cx32) cause a demyelinating neuropathy called X-linked Charcot-Marie-Tooth disease (CMTX) (Bergoffen et al., 1993). The connexins are a family of $>20$ proteins that comprise the intercellular channels of gap junctions (Evans and Martin, 2002). These channels connect the cytoplasm of adjacent cells directly and can be permeated by ions and a variety of small molecules. In neurons they constitute electrical synapses, and in nonexcitable cells they provide a mechanism for signal transduction contributing to organ development (Levin, 2002) and homeostasis (White and Paul, 1999). In Schwann cells, it has been proposed that gap junctions provide a pathway for the diffusion of molecules directly across the myelin sheath (Bergoffen et al., 1993).

More than 240 different Cx32 mutations cause CMTX, but only a few of these are associated with CNS abnormalities (Kleopa and Scherer, 2002). However, both Schwann cells and oligodendrocytes express Cx32 (Scherer et al., 1995), raising the question of whether CNS and PNS myelination are fundamentally different in terms of a requirement for gap junctional communication or connexin-based channel activity. One possible explanation is that the loss of $\mathrm{Cx} 32$ in oligodendrocytes is compensated by the

Received March 25, 2003; revised May 9, 2003; accepted May 14, 2003.

This work was supported by National Institutes of Health Grants R01 GM37751 (D.L.P.), R01 NS42878 (S.S.S.) R01 GM18974 (D.A.G.) and P30-HD18655 (Mental Retardation Research Center at Children's Hospital, Boston). We thank Susan Shumas, Caterina Sellitto, Antonio Gomes, and especially Marta Mastroianni for expert technical assistance.

Correspondence should be addressed to Dr. David L. Paul, Department of Neurobiology, Harvard Medical School, 220 Longwood Avenue, Boston, MA 02115. E-mail:dpaul@hms.harvard.edu.

Copyright $\odot 2003$ Society for Neuroscience $\quad$ 0270-6474/03/235963-11\$15.00/0 expression of additional connexins providing redundant functionality. Indeed, we recently identified Cx29, a novel connexin whose expression is restricted to myelinating glial cells (Altevogt et al., 2002; Li et al., 2002). However, the distribution of Cx29 and $\mathrm{Cx} 32$ proteins was primarily nonoverlapping in mouse spinal cord oligodendrocytes and Cx29 distribution was not altered in a Cx32 KO. Thus, Cx29 alone might not be able to account for normal myelination in the absence of $\mathrm{Cx} 32$.

Here, we report the characterization of $\mathrm{Cx} 47$, which is expressed in most if not all oligodendrocytes, whose expression is regulated in parallel with other myelin genes. Like mice lacking Cx32 (Nelles et al., 1996), mice lacking Cx47 are viable and fertile. However, animals lacking both $\mathrm{Cx} 47$ and $\mathrm{Cx} 32$ develop a profound CNS demyelination associated with gross tremors and tonic seizures that cause death by the fifth to sixth postnatal week. Together with our previous studies, these findings indicate that the expression of multiple connexins is a general property of myelinating glial cells and that connexins are required for normal myelination in both the CNS and the PNS.

\section{Materials and Methods}

Northern blot analysis. For RNA extraction, the spinal cord, brain, liver, and kidney were taken from adult wild-type mice and the brain from adult Sprague Dawley rats and myelin-deficient $(m d)$ rats. Total RNA was isolated by $\mathrm{CsCl}_{2}$ gradient centrifugation. Equal samples $(10 \mu \mathrm{g})$ of RNA were electrophoresed in $1 \%$ agarose, $2.2 \mathrm{M}$ formaldehyde gels, transferred to nylon membranes in $6 \times$ SSC, and UV cross-linked $(0.12 \mathrm{~J})$. Blots were prehybridized, hybridized, and washed using standard techniques; the final wash was at $60^{\circ} \mathrm{C}$ in $0.1 \times$ SSC for $30 \mathrm{~min}$. cDNA probes were ${ }^{32} \mathrm{P}$-labeled with specific activities of $2-5 \times 10^{9} \mathrm{cpm} / \mathrm{ng}$, by primer extension with random hexamers using the Prim-a-gene kit (Promega, Madison, WI), according to the manufacturer's instructions. The following cDNAs were used as probes: a $1.1 \mathrm{~kb}$ EcoRI fragment of the coding region of rat Cx32 (Paul, 1986), a full-length rat proteolipid protein (PLP) (Milner et al., 1985), and full-length rat glyceraldehyde-3phosphate dehydrogenase (Fort et al., 1985). Two Cx47 fragments were used as a probe: a 315 bp fragment and a 511 bp fragment (between 
A

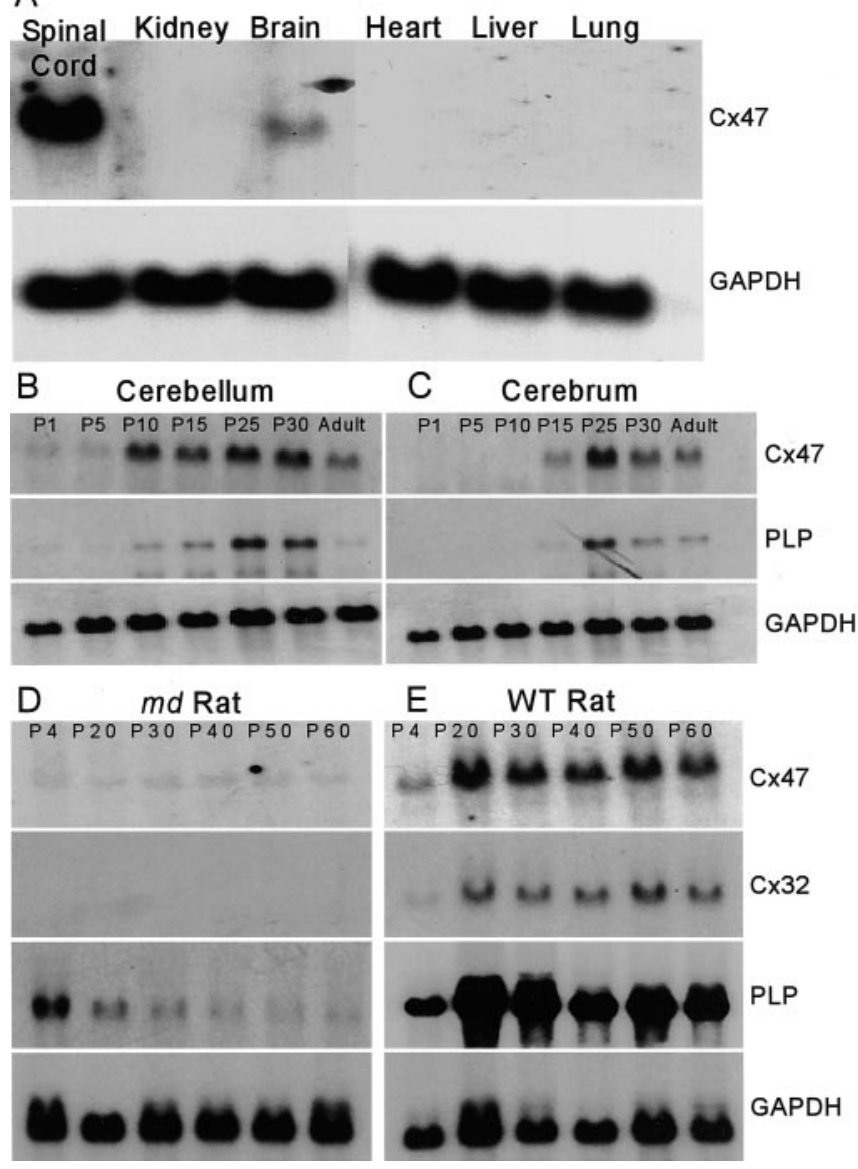

Figure 1. Cx47 mRNA is predominantly expressed in the CNS and regulated like a myelin-related gene. $A$, Northern blot of total RNA from various adult mouse tissues. CX47 mRNA is detected only in spinal cord and brain. $B, C$, Northern blot of total RNA from developing mouse cerebellum and cerebrum. Temporal regulation of $\mathrm{X} 47$ transcript parallels that of PLP.D, E, Northern blot of total RNA from $m d$ and WT rat brain during postnatal development. $m d$ and WT RNA samples were obtained from littermates and processed for blotting under identical conditions. The levels of $\mathrm{Cx} 47, \mathrm{C} \times 32$, and PLP mRNA are lower in $m d$ rats, which carry a point mutation in PLP, resulting in profound CNS dysmyelination. GAPDH, Glyceraldehyde-3-phosphate dehydrogenase.

positions $1381-1695$ and $664-1174$ of the mouse Cx47 coding region, respectively.)

In situ hybridization. For in situ hybridization, postnatal day 30 (P30) to P60 mice were killed following Institutional Animal Care and Use Committees guidelines. The brain and spinal cord were dissected and fixed for $1 \mathrm{hr}$ at room temperature in $4 \%$ paraformaldehyde, rinsed with PBS, and cryoprotected overnight in $30 \%$ sucrose/PBS. Tissue was embedded in optimal cutting temperature compound (OCT; Tissue-Tek, Miles Inc., Elkhart, IN), frozen, sectioned at $8 \mu \mathrm{m}$ and collected on SuperFrost Plus slides (Fisher Scientific, Pittsburgh, PA). In situ hybridization was performed using a single-stranded digoxigenin UTP-labeled RNA probe. To ensure specificity, two different probes were used: a 315 bp fragment (nucleotides 1381-1695 of the coding region) corresponding to the least conserved region among different connexins, and a $511 \mathrm{bp}$ fragment, (nucleotides 664-1174 of the coding region). The fragments were subcloned into pBluescript SK- (Stratagene, La Jolla, CA) for riboprobe synthesis. Both produced identical patterns of in situ labeling. A 747 bp fragment of the coding region of mouse DM20/PLP was also prepared. In situ hybridization was performed as described previously (Bao and Cepko, 1997), with the following changes. The sections were fixed with $4 \%$ paraformaldehyde at room temperature for $15 \mathrm{~min}$, and hybridization was performed overnight at $72^{\circ} \mathrm{C}$ with probes at $1 \mu \mathrm{g} / \mathrm{ml}$.

Preparation of anti-Cx47 antibody. The nucleotides corresponding to amino acids 332-436 were cloned into pGEX-4T-3 and a fusion protein encoding glutathione-S-transferase (GST) plus the C-terminal portion of $\mathrm{Cx} 47$ was produced and purified using standard procedures (Jiang et al., 1994). Rabbits were immunized (Pocono Rabbit Farm, Canadensis, $\mathrm{PA}$ ), and the resultant antiserum was affinity-purified using columnbound Cx47-GST fusion protein.

Western blot analysis. Wild-type spinal cord, brain, and liver were dissected and homogenized in buffer containing $50 \mathrm{~mm}$ Tris, $\mathrm{pH}$ 7.6, $1 \%$ SDS, $0.017 \mu \mathrm{g} / \mathrm{ml}$ phenylmethylsulfonylfluoride, $0.05 \mu \mathrm{g} / \mathrm{ml}$ Sigma (St. Louis, MO) protease inhibitor cocktail (P8340), $18.5 \mu \mathrm{g} / \mathrm{ml}$ diisopropylfluorophosphate, sonicated and combined with $2 \times$ SDS-PAGE loading buffer (150 mM Tris, pH 7.6, 6\% SDS, 30\% glycerol, 0.3\% bromophenol blue, $300 \mathrm{~mm}$ DTT). Positive and negative controls for Western blotting were obtained by transfection of COS cells with a eukaryotic expression vector containing the mouse $\mathrm{Cx} 47$ coding sequence or the vector (pCMV-IRES2-EGFP; Clontech, Cambridge, UK) alone, respectively.

The amount of protein in each sample was measured using the DC protein assay (Bio-Rad, Hercules, CA) according to the manufacturer's instructions; $10 \mu \mathrm{g}$ of protein was loaded per lane. After separation on $4-20 \%$ acrylamide gels, proteins were transferred at $100 \mathrm{~V}$ for $70 \mathrm{~min}$ in $1 \times$ transfer buffer $(0.2 \%$ methanol, $2.5 \mathrm{~mm}$ Tris, $19.2 \mathrm{~m}$ glycine $)$ onto Protran nitrocellulose pore $0.45 \mathrm{~mm}$ (Schleicher \& Schuell, Keene, NH). Membranes were blocked with $5 \%$ nonfat dry milk in $1 \times \mathrm{PBS}$ and $0.1 \%$ Tween 20 (PBS-Tween), overnight at $4^{\circ} \mathrm{C}$ and incubated for $3 \mathrm{hr}$ at room temperature in affinity-purified anti-Cx47 (1:2000 in 5\% nonfat dry milk in $1 \times$ PBS-Tween). Blots were washed five times for $5 \mathrm{~min}$ in PBS-Tween and then incubated in 1:5000 anti-rabbit HRP-conjugated secondary antibody (170-6515; Biorad) in 5\% nonfat dry milk, $1 \times$ PBS, $0.1 \%$ Tween 20, for $1 \mathrm{hr}$ at room temperature, and washed five times for $5 \mathrm{~min}$ in PBS-Tween; antibody binding was detected using the Amersham Biosciences (Arlington Heights, IL) ECL kit, according to the manufacturer's instructions.

Immunohistochemistry. Mice were perfused using freshly prepared $4 \%$ paraformaldehyde in $0.1 \mathrm{~m}$ phosphate buffer (PB), $\mathrm{pH} 7.4$; the spinal cord, brain, and optic nerve were dissected and infiltrated in $20 \%$ sucrose PB overnight before embedding in OCT. Cryosections $(8 \mu \mathrm{m})$ were thaw-mounted on SuperFrost Plus glass slides (Fisher Scientific, Houston, TX) and stored at $-20^{\circ} \mathrm{C}$. Sections were postfixed and permeabilized by immersion in $-20^{\circ} \mathrm{C}$ acetone for $10 \mathrm{~min}$, washed in PBS, blocked for at least $1 \mathrm{hr}$ in $5 \%$ goat serum, $0.1 \%$ Triton X-100 in PBS, and incubated overnight at $4^{\circ} \mathrm{C}$ with various combinations of primary antibodies: AntiCx47 (1:1000); mouse anti-Cx32 (7C6.C7, 1:2; Li et al., 1997); mouse anti-GFAP (Sigma clone G-A-5 at 1:300), mouse anti-neuronal nuclei (NeuN) (1:100; Chemicon, Temecula, CA), and mouse anti-CC1 (Ab-7 at 1:20; Oncogene Sciences, Uniondale, NY).

After incubating with the primary antibodies, the slides were washed and incubated either with fluorescein-conjugated donkey cross-affinitypurified secondary antibodies (diluted 1:100; Jackson ImmunoResearch, West Grove, PA) or Cy3-conjugated goat anti-mouse secondary antibody (diluted 1:200; Chemicon). Slides were mounted with Vectashield (Vector Laboratories, Burlingame, CA) and examined with a Zeiss (Oberkochen, Germany) LSM 510 laser scanning confocal microscope followed by image manipulation with Adobe Photoshop (Adobe Systems, San Jose, CA).

Production of connexin knock-outs. Cx47 genomic clones were obtained from a $129 \mathrm{sv}$ genomic phage library (Stratagene, La Jolla, CA) using a full-length coding region probe corresponding to the human Cx46.6 sequence (GenBank accession number AF014643). Preparation of the targeting vector and embryonic stem (ES) cell transfection were performed using conventional techniques (White et al., 1998). Homologous recombinants were identified by PCR screening at a frequency of 1 in 25 neoresistant colonies. Two independent stem-cell clones were injected into C57BL/6 blastocysts. Both produced founders exhibiting germ-line transmission. Mice were maintained in a mixed 129sv/ C57BL/6 background. To obtain double knock-outs and control wildtype (WT) littermates, female $\mathrm{Cx} 47 / \mathrm{Cx} 32$ double heterozygotes were crossed with male $\mathrm{Cx} 32$ knock-out/Cx47 heterozygotes. Because $\mathrm{Cx} 32$ is $\mathrm{X}$-linked, one of eight males was WT for both connexins.

Semithin section and electron microscopy. Mice were deeply anesthetized with chloral hydrate, then perfused with $0.9 \% \mathrm{NaCl}$ followed by $3 \%$ 


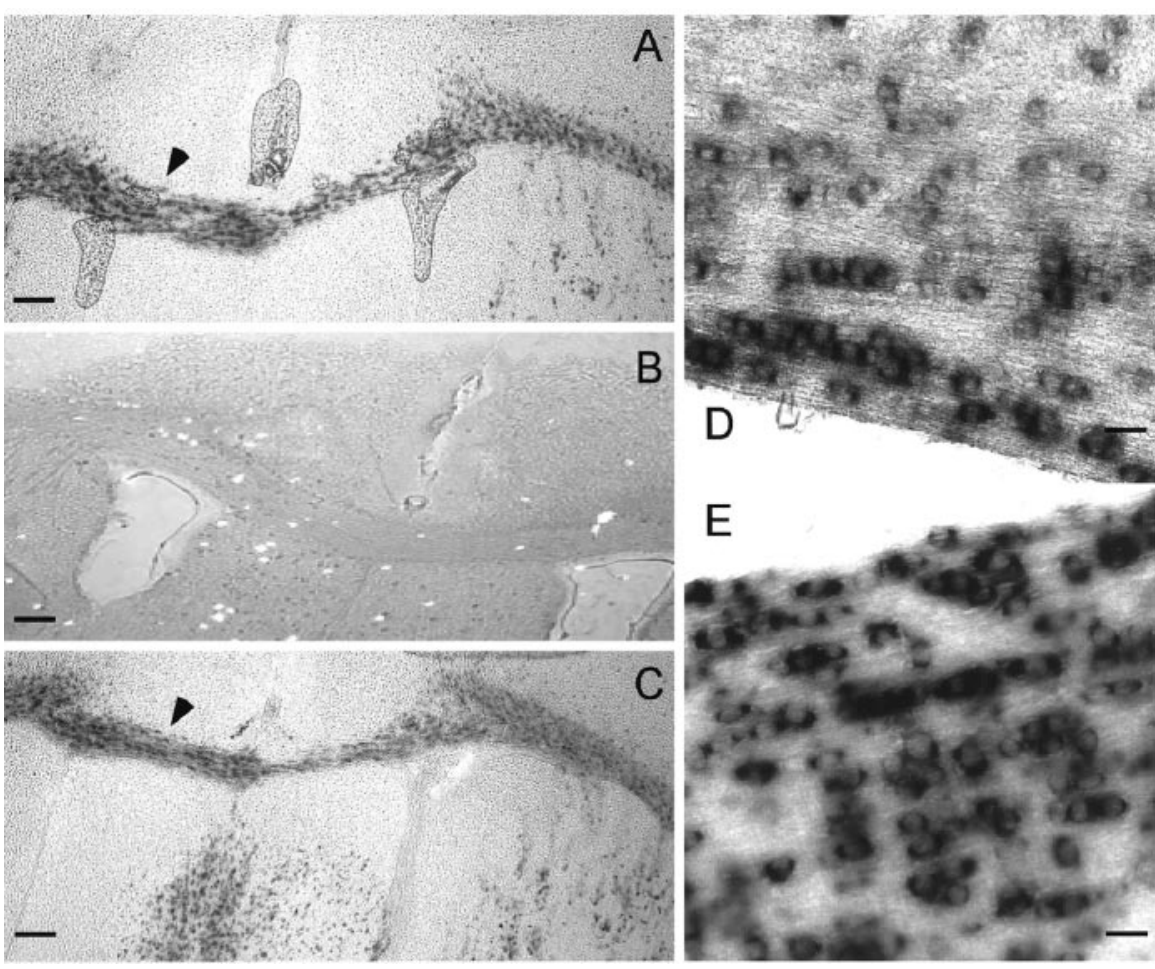

Figure 2. ISH for Cx47 mRNA in brain and spinal cord. $A-C$, Coronal sections through adult mouse brain hybridized with a $C \times 47$ antisense riboprobe $(A)$, a control $C x 47$ sense riboprobe $(B)$, or a PLP antisense riboprobe $(C)$. $C x 47$ is most abundant in whitematter tracts, such as the corpus callosum, a pattern similar to that of PLP. D, E, Longitudinal sections of adult mouse spinal cord hybridized for $\mathrm{Cx} 47(D)$ or PLP $(E)$. Labeled cells are arranged in chains, characteristic of intrafascicular oligodendrocytes. Scale bars: $A-C, 500 \mu \mathrm{m} ; D, E, 150 \mu \mathrm{m}$.

glutaraldehyde in $0.1 \mathrm{M} \mathrm{PB}, \mathrm{pH}$ 7.4. Tissues were removed and placed in fresh fixative overnight at $4^{\circ} \mathrm{C}$. For electron microscopy, tissues were rinsed in $\mathrm{PB}$, postfixed in $2 \% \mathrm{OsO}_{4}$ in $\mathrm{PB}$ for $1 \mathrm{hr}$, dehydrated in graded ethanols, infiltrated, and embedded in epoxy. Semithin sections were stained with toluidine blue; thin sections were stained with lead citrate.

\section{Results}

A search of GenBank for connexin-related sequences identified a novel human connexin designated Cx46.6 (accession number

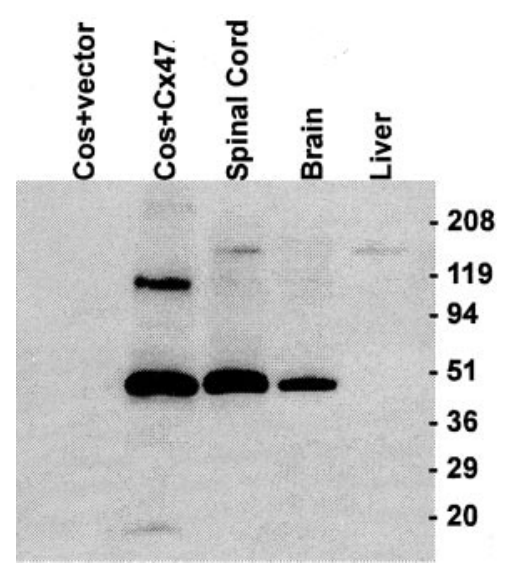

Figure 3. Western blot characterization of an anti-Cx47 serum. Bands at $\sim 47$ and at $\sim 100$ $\mathrm{kDa}$ are evident in $\mathrm{COS}$ cells transiently transfected with an expression vector containing the mouse $\mathrm{Cx} 47$ open reading frame, but not with an empty vector. The higher-molecular-mass band is most likely a dimerization artifact (see text). A specific signal was observed in adult mouse brain and spinal cord but not in liver.
AF014643) and a fragment corresponding to the putative coding region was used to probe a Northern blot of RNA from mouse tissues (Fig. 1 $A$ ). Expression was evident only in brain and spinal cord, consistent with an association of this connexin with glial cells. The same probe was used to screen a mouse genomic library and obtain a murine ortholog, which encoded a 46.6 $\mathrm{kDa}$ protein with $84 \%$ identity to the human version. The mouse sequence corresponds to a previously reported connexin designated Cx47 (GenBank accession number AJ276435) (Teubner et al., 2001).

\section{$\mathrm{Cx} 47$ is a myelin-related gene}

To evaluate further the expression of $\mathrm{Cx} 47$ in the CNS, we examined the developmental profile of $\mathrm{Cx} 47 \mathrm{mRNA}$ in mouse cerebellum and cerebrum (Fig. $1 B, C$ ). The temporal profile in the level of $\mathrm{Cx} 47$ mRNA was similar to that of other myelinrelated genes, which we confirmed by reprobing the blots for PLP mRNA, which encodes an abundant intrinsic membrane protein of compact myelin. We also examined Cx47 mRNA levels in the md rat, which carries a $P l p$ mutation that results in a failure of oligodendrocyte maturation and myelin formation (Grinspan et al., 1998). The levels of Cx47, Cx32, and PLP mRNA were much lower in $m d$ rats (Fig. $1 D$ ) than in their male littermates (Fig. $1 E)$. Together, these data support the idea that oligodendrocytes express Cx47, in addition to both Cx32 (Scherer et al., 1995) and Cx29 (Altevogt et al., 2002), as part of a program of myelin gene expression.

\section{$\mathrm{Cx} 47$ is expressed by oligodendrocytes and not neurons or astrocytes}

Previously, Teubner et al. (2001) characterized Cx47 as a neuronal product on the basis of in situ hybridization (ISH). To resolve the discrepancy between their results and our RNA expression data, we performed ISH. Coronal sections of adult mouse brain hybridized with antisense $\mathrm{Cx} 47$ riboprobe (Fig. $2 \mathrm{~A}$ ) reveal that expression was primarily evident in white-matter tracts such as the corpus callosum. A sense control displayed a relatively low background (Fig. $2 \mathrm{~B}$ ), and the pattern of $\mathrm{Cx} 47 \mathrm{mRNA}$ expression was similar to that of PLP, an oligodendrocyte marker (Fig. 2C). Moreover, in higher-magnification micrographs of longitudinally sectioned spinal cord, cells expressing $\mathrm{Cx} 47$ (Fig. 2D) or PLP (Fig. 2E) are arranged in distinctive chains within the white matter, characteristic of intrafascicular oligodendrocytes.

To confirm that oligodendrocytes express Cx47 and determine its distribution within the cells, we produced an affinitypurified anti-Cx47 antibody using a GST-fusion protein containing the majority of the C-terminal domain. Western blotting was used to characterize the fusion-protein antibody (Fig. 3). For positive and negative controls, total proteins were prepared from COS cells transiently transfected with an expression vector containing the mouse $\mathrm{Cx} 47 \mathrm{cDNA}$ or with the empty vector. $\mathrm{Cx} 47$ - 
transfected cells displayed a major immunoreactive band at $\sim 47 \mathrm{kDa}$ and a less intensely labeled band at $\sim 100 \mathrm{kDa}$, whereas cells transfected with empty vector displayed no bands. The $\sim 100 \mathrm{kDa}$ band is likely to be stable dimers of SDSsolubilized $\mathrm{Cx} 47$, similar to those observed for Cx32 (Hertzberg, 1984) and Cx29 (Altevogt et al., 2002). Consistent with the Northern blot, strong labeling of an $\sim 47$ $\mathrm{kDa}$ band was observed in the spinal cord and brain but not the liver.

This antibody was used to label transverse sections of mouse spinal cord (Fig. 4). Cx47 staining consisted of numerous intensely fluorescent puncta that outlined cell bodies (arrow) and processes (arrowhead) (Fig. 4A). Double-labeling was performed for $\mathrm{Cx} 47$ and either CC1, NeuN, or GFAP, markers for oligodendrocytes (Bhat et al., 1996), neurons (Mullen et al., 1992), and astrocytes (Debus et al., 1983), respectively. All CC1-positive cell bodies (Fig. $4 B$, red) were also positive for $\mathrm{Cx} 47$ (green). Conversely, all Cx47-positive cell bodies were labeled for CC1. In contrast, the overall distributions of $\mathrm{Cx} 47$ and either NeuN (Fig. 4C) or GFAP (Fig. 4D) were clearly distinct, and at a cellular level, overlap was never detected. Thus, $\mathrm{Cx} 47$ was expressed by most, if not all, spinal cord oligodendrocytes but not by neurons or astrocytes. Similar results were obtained in other regions of the CNS, including the corpus callosum, cerebellum and optic nerve (data not shown).

\section{Cx47 and Cx32 display a partially overlapping distribution}

The spatial relationship of $\mathrm{Cx} 47$ and $\mathrm{Cx} 32$ was assessed by double-labeled immunocytochemistry in transverse sections of spinal cord (Fig. 5). In gray matter (Fig. 5A), oligodendrocyte cell bodies were outlined by large puncta. The majority of these were labeled for both $\mathrm{Cx} 47$ (green) and Cx32 (red), consistent with the notion that these two connexins were contained within a single gap junction. Although most of the $\mathrm{Cx} 47$ puncta were associated with cell bodies, $\mathrm{Cx} 32$ was also evident in a substantial number of smaller plaques dispersed throughout the neuropil (Scherer et al., 1995; Rash et al., 1996). Because Cx32 and Cx29 do not generally colocalize (Altevogt et al., 2002), this staining likely represents gap junctions at which the oligodendrocyte contributes only $\mathrm{Cx} 32$ or $\mathrm{Cx} 32$ in combination with an as-yet uncharacterized connexin.

In white matter, oligodendrocyte cell bodies were also surrounded by numerous $\mathrm{Cx} 47$ puncta. As in gray matter, cell bodyassociated plaques were primarily double-labeled for Cx32 (data not shown). Puncta in oligodendrocyte processes were far more numerous in spinal cord white matter than in gray (Fig. $5 B$ ). Cx47-positive puncta were often aligned in a manner suggesting association with myelinating fibers. As in gray matter, the majority of Cx47 signal colocalized with Cx32, whereas many dispersed puncta were positive only for $\mathrm{Cx} 32$. Thus, $\mathrm{Cx} 32$ and $\mathrm{Cx} 47$ display a high overall level of colocalization, consistent with the hypothesis that they might provide similar and redundant functions.

\section{Either $\mathrm{Cx} 47$ or $\mathrm{Cx} 32$ is required for normal CNS myelin}

To determine whether $\mathrm{Cx} 47$ is required for CNS myelination, a knock-out mouse was produced. The targeting strategy (Fig. 6A), removed the $\mathrm{N}$ terminal and all four transmembrane domains as well as a substantial portion of the $5^{\prime}$ untranslated region, leaving only a small amount of the C-terminal coding region intact. Homologous recombination was verified in both ES cells and animals using PCR for the $5^{\prime}$ aspect and Southern blotting for the $3^{\prime}$ aspect of the locus (Fig. 6B,C), and loss of Cx47 mRNA and protein in vivo was verified using Northern and Western blotting (Fig. 6D,E).

As with the Cx32 KO (Nelles et al., 1996), the Cx47 KOs displayed no obvious behavioral abnormality (data not shown). Furthermore, just as no CNS demyelination has been detected in Cx32 KO mice (Scherer et al., 1998), no demyelination was detected in semithin sections of Cx47 KO spinal cords of animals ranging from 12 to 26 weeks of age (data not shown). To explore the possibility that $\mathrm{Cx} 32$ and $\mathrm{Cx} 47$ provide redundant activity, we produced double knock-outs (dKOs) by crossing $C \times 47$ and $C \times 32$ KOs. The dKO developed a coarse action tremor during the third postnatal week (data not shown). The tremor was accentuated on movement, and its severity worsened over time. During the fourth to fifth postnatal week, the $\mathrm{dKO}$ mice began to exhibit tonic seizures, characterized by limb extension and loss of consciousness. The seizures increased in frequency and severity until the animals died, typically during the sixth postnatal week.

Because the behavior of the dKOs was consistent with CNS abnormalities, we examined the integrity of CNS white matter using semithin sections of the optic nerve, spinal cord, and pons in $\mathrm{dKO}$ mice at P31 (Fig. 7), when their behavioral abnormalities were advanced. There was extensive pathology in the CNS, confined to myelinated fiber tracts. In the dorsal, lateral, and ventral funiculi of the spinal cord, many of the largest myelinated axons 

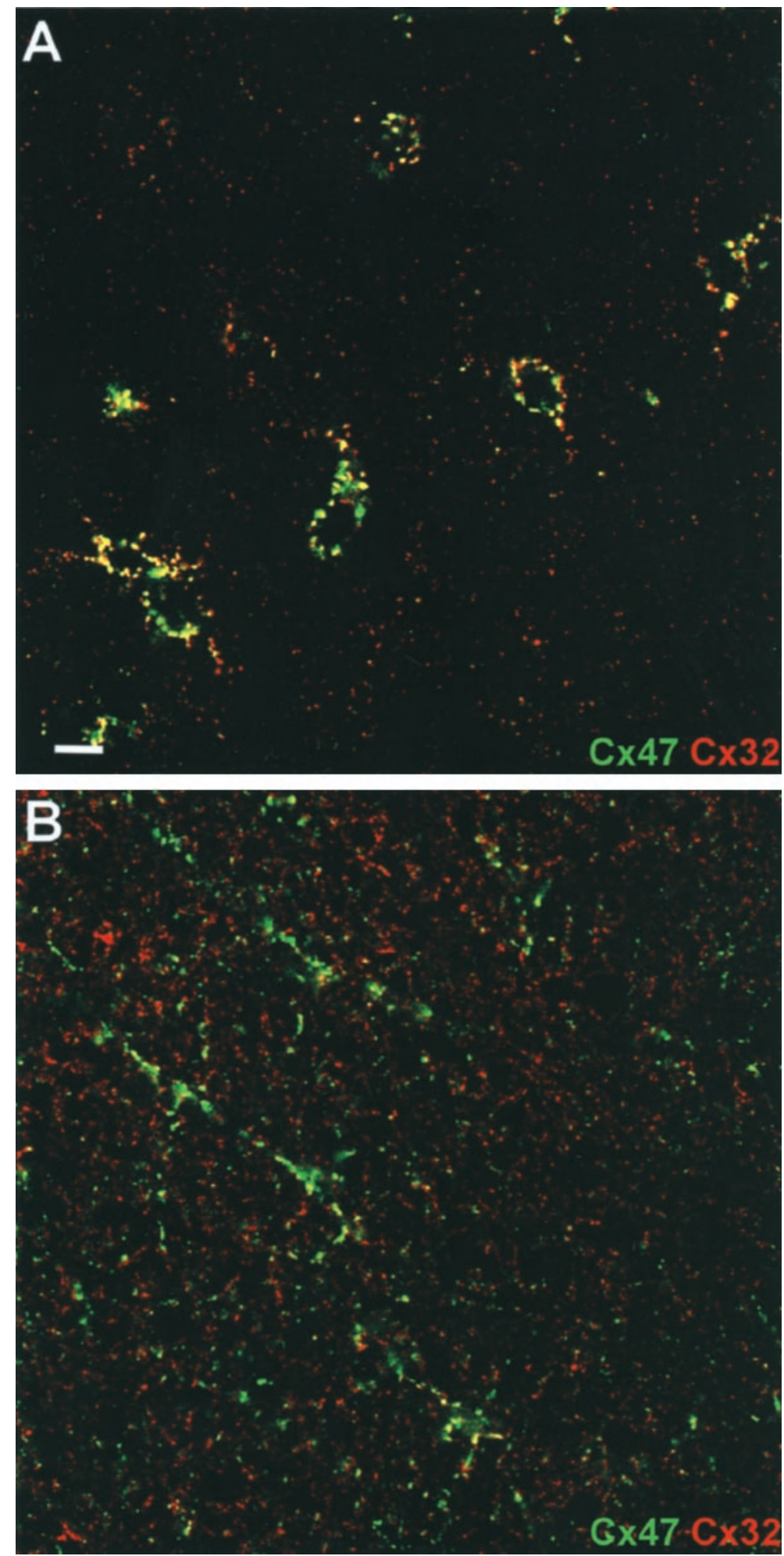

Figure 5. $\quad(x 47$ and $(x 32$ colocalize in oligodendrocyte cell bodies and processes. Confocal micrographs of adult mouse spinal cord gray matter $(A)$ or white matter $(B)$ double-stained for $C \times 47$ (green) and $C \times 32$ (red). In gray matter, numerous puncta around oligodendrocyte cell bodies and processes contain both $\mathrm{Cx} 47$ and $\mathrm{Cx32}$ (yellow). However, away from the cell body in the neuropil, Cx47 and Cx32 do not colocalize. Scale bar, $6 \mu \mathrm{m}$.

had myelin sheaths that were thinner (Fig. 7D) than those found in age-matched littermates (Fig. 7C). In addition, there were numerous myelinated axons with markedly enlarged extracellular spaces separating the axon from its myelin sheath, macrophages containing myelin debris, demyelinated axons, and occasional myelinated axons with enlarged collars of periaxonal oligodendrocyte cytoplasm. Similar findings were evident in the optic nerve, where one could also appreciate a pronounced loss of myelinated axons (Fig. 7, compare $A$ and $B$ ). The myelinated fibers in other brains regions were affected, although some tracts appeared to be relatively spared. For example, Figure $7 E$ shows a portion of the corticobulbar tract in the pons, which contains numerous small myelinated axons. There are a large number of vacuolated myelin sheaths and macrophages containing myelin debris. In contrast, the intramedullary trigeminal nerve in the pons (Fig. $7 F$ ) contains many large axons that are normally myelinated; no vacuolated myelin sheaths are evident. Finally, there were apoptotic cells (data not shown) in the affected tracts, suggesting that oligodendrocyte cell death was part of the pathological process.

To confirm and extend these findings, the spinal cord was also examined by electron microscopy (Fig. 8). Myelin sheaths were generally thinner (Fig. $8 \mathrm{~A}$, arrow) and the intrusion of oligodendrocyte cytoplasm (p) into the space between the axon and the oligodendrocyte was observed. Many axons of a caliber consistent with myelination in WT animals displayed no obvious myelin in the dKOs (Fig. $8 \mathrm{~B}$ ). In addition, this analysis confirmed that many axons were separated from their myelin sheaths by a markedly enlarged extracellular space (Fig. 8C). These axons, like frankly demyelinated axons, typically had more tightly packed neurofilaments. Some myelin sheaths contained no axon, presumably because of axonal degeneration. Finally, the ultrastructural characteristics of the apoptotic cells suggested that they were oligodendrocytes (Fig. 8D). Together, these data demonstrate that the combined loss of $\mathrm{Cx} 32$ and $\mathrm{Cx} 47$ results in a complex pathological picture featuring demyelination and oligodendrocyte cell death.

To evaluate the development of these pathological changes, we examined the optic nerve (Fig. 9), in which myelination has been extensively characterized (Matheson, 1970; Tennekoon et al., 1977; Devaux et al., 2002). At P7, the largestdiameter fibers in WT optic nerve were already invested with myelin, although the majority of fibers were unmyelinated. In contrast, the largest fibers in the $\mathrm{dKO}$ had no myelin sheaths. Peak myelination in the optic nerve occurs between P14 and P21, and as expected, the number of myelinated fibers in WT nerve had increased substantially by P14. At this age, the dKOs also displayed a substantial number of myelinating axons. However, the distinctive morphological abnormalities, 


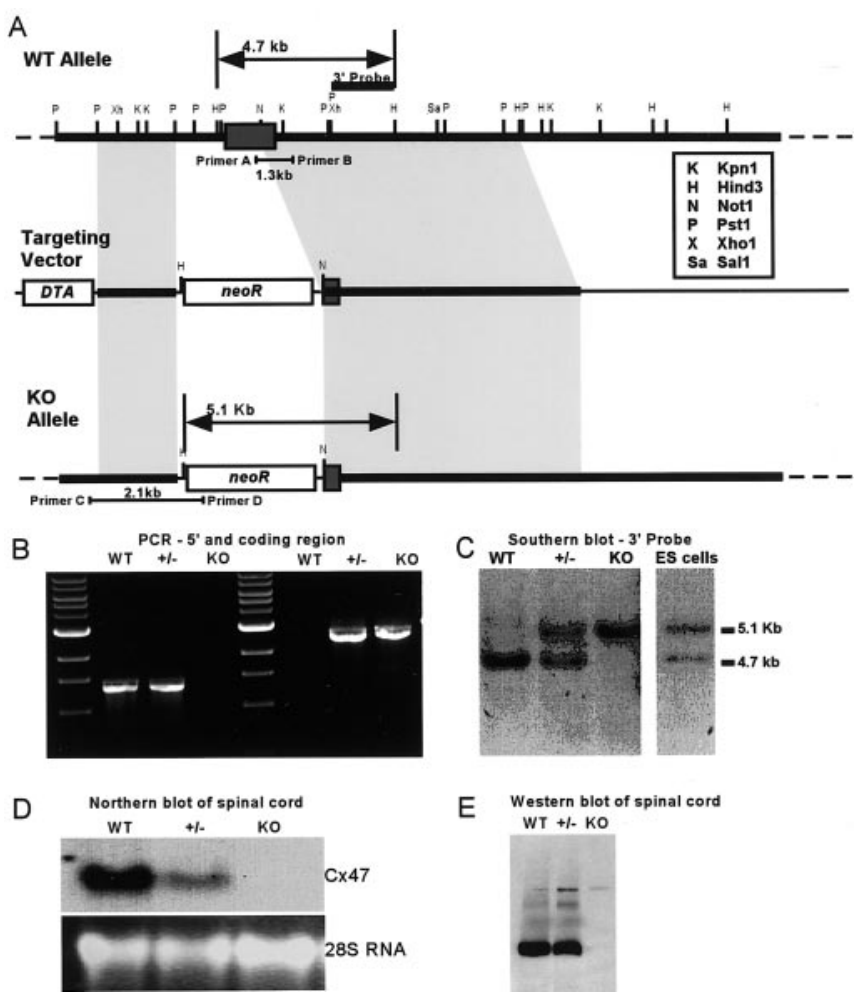

Figure 6. Targeting strategy for $C x 47$. A, Top, WT C $x 47$ locus showing the single exon of $C x 47$ (dark gray box). Middle, A neo cassette replaced most of the $\mathrm{C} x 47$ coding region in the targeting vector. $A$, Bottom, The $C x 47$ knock-out allele after homologous recombination. $B, 5^{\prime}$ recombination was verified by $P C R$ of tail DNA. Primer pair $A / B(A$, top) produced a $1.3 \mathrm{~kb}$ amplicon only in WT and + / - samples, whereas primer pair C/D produced a $2.1 \mathrm{~kb}$ amplicon only in + / and $\mathrm{KO}$ samples. $C, 3^{\prime}$ recombination was verified by Southern blotting HindllI digests of WT, $+/-$, and K0 tail DNA, and recombinant ES-cell DNA using the $3^{\prime}$ probe designated in A. A 4.7 $\mathrm{kb}$ WT allele and a $5.1 \mathrm{~kb}$ recombined allele were detected. D, Loss of Cx47 expression in vivo. A single band was detected in WT RNA. Cx47 RNA levels were reduced in the $+1-$ and were undetectable in the KO. Similarly, a Western blot confirmed the absence of Cx47 protein in the $\mathrm{KO}(E)$.

thin sheaths, oligodendrocyte cytoplasmic inclusion, and vacuolation were evident in some fibers. At P21, myelination was largely completed in the WT nerve, and all fibers were ensheathed, whereas in the $\mathrm{dKO}$, many axons had thin myelin sheaths or no myelin sheaths at all. In addition, as in the P31 spinal cord, there were "empty" myelin sheaths in which the axons had presumably degenerated.

\section{Discussion}

The observation that $C \times 32$ mutations cause peripheral but not central demyelination, although $\mathrm{Cx} 32$ is expressed in both Schwann cells and oligodendrocytes, led us to look for other connexins expressed by oligodendrocytes. Here we show that Cx47 is expressed predominantly, if not exclusively, in oligodendrocytes, and that most $\mathrm{Cx} 47$-positive gap junction plaques also contain $\mathrm{Cx} 32$. Although the loss of either $\mathrm{Cx} 32$ or $\mathrm{Cx} 47$ alone does not result in an obvious CNS phenotype, the loss of both profoundly affects CNS myelination. These data provide the first direct evidence for both the importance of gap junction-mediated communication in central myelination and functional redundancy of connexins in oligodendrocytes.

\section{Connexins in oligodendrocytes}

Oligodendrocytes express at least three connexins in complex and overlapping patterns. Cx32 is present in gap junction plaques on oligodendrocyte cell bodies and proximal processes (Dermietzel et al., 1989; Scherer et al., 1995; Kunzelmann et al., 1997; Rash et al., 2001; Altevogt et al., 2002). In contrast, Cx29 is generally not evident in oligodendrocyte cell bodies. It is abundant in small plaques along processes, particularly myelin sheaths associated with smaller axons, especially in the juxtaparanodal region, but it does not colocalize with Cx32 (Altevogt et al., 2002). Distinctly different distributions of Cx32 and Cx29 are also observed in myelinating Schwann cells (Altevogt et al., 2002; Li et al., 2002). Here, we show that $\mathrm{Cx} 47$ is expressed by oligodendrocytes and is confined primarily to plaques that also contain Cx32. Like Cx32, Cx47 showed little if any overlap with Cx29 (data not shown). The extensive overlap of $\mathrm{Cx} 32$ and $\mathrm{Cx} 47$ at the light microscopic level is consistent with the notion that they have similar and redundant activities in oligodendrocytes. Furthermore, $\mathrm{Cx} 32$ and $\mathrm{Cx} 47$ have been colocalized in gap junctions between oligodendrocytes and astrocytes at the electron microscopic level using freeze-fracture immunogold labeling (J. Rash, personal communication).

Several studies report that oligodendrocytes express $\mathrm{Cx} 45$ (Dermietzel et al., 1997; Kunzelmann et al., 1997; Pastor et al., 1998). However, oligodendrocytes do not express the reporter gene (data not shown) in mice in which the $\mathrm{Cx} 45$ coding region is replaced with $\beta$-galactosidase (Kruger et al., 2000; Kumai et al., 2000). This discrepancy remains to be explained. In addition, $\mathrm{Cx} 47$ was originally reported to be neuron-specific (Teubner et al., 2001) on the basis of the pattern of ISH. In contrast, the ISH that we report here indicates that $\mathrm{Cx} 47$ is expressed primarily if not exclusively in myelinating oligodendrocytes, a conclusion that is strongly substantiated by immunostaining for $\mathrm{Cx} 47$ and the phenotype of the double $C \times 32 / C \times 47 \mathrm{KO}$ mice.

\section{Intercellular communication in oligodendrocytes}

Gap junctions are evident in at least four types of cells comprising the CNS: astrocytes, ependymocytes, oligodendrocytes, and neurons. However, it is clear from extensive ultrastructural studies that each cell type establishes gap junctions in specific and limited patterns. Oligodendrocytes form gap junctions only with astrocytes and not with other oligodendrocytes (Massa and Mugnaini, 1982; Waxman and Black, 1984; Nagy et al., 1997; Rash et al., 2001). In contrast, astrocytes form large numbers of gap junctions with other astrocytes in addition to the ones made with oligodendrocytes. Furthermore, physiological studies reveal extensive gap junctional communication between astrocytes (see below), indicating that at least some of the glial gap junctions observed by electron microscopy are indeed functional. Together, these observations have led to the notion that gap junctions connect macroglia into a "panglial syncytium" (Massa and Mugnaini, 1982; Rash et al., 1997).

Physiological studies of gap junctional intercellular communication (GJIC) involving oligodendrocytes suggest heterogeneity and are often inconsistent with the distribution of gap junctions described above. In cell culture studies, GJIC between astrocytes and oligodendrocytes has been demonstrated with dye transfer and electrical measurements (Kettenmann et al., 1983; Massa et al., 1984; Venance et al., 1995). In contrast, dye injection into rat optic nerve astrocytes resulted in transfer to other astrocytes but not to oligodendrocytes (Butt and Ransom, 1989). Dye coupling was also reported in the myelinated band of the rabbit retina (Robinson et al., 1993), but the pattern was unexpectedly 

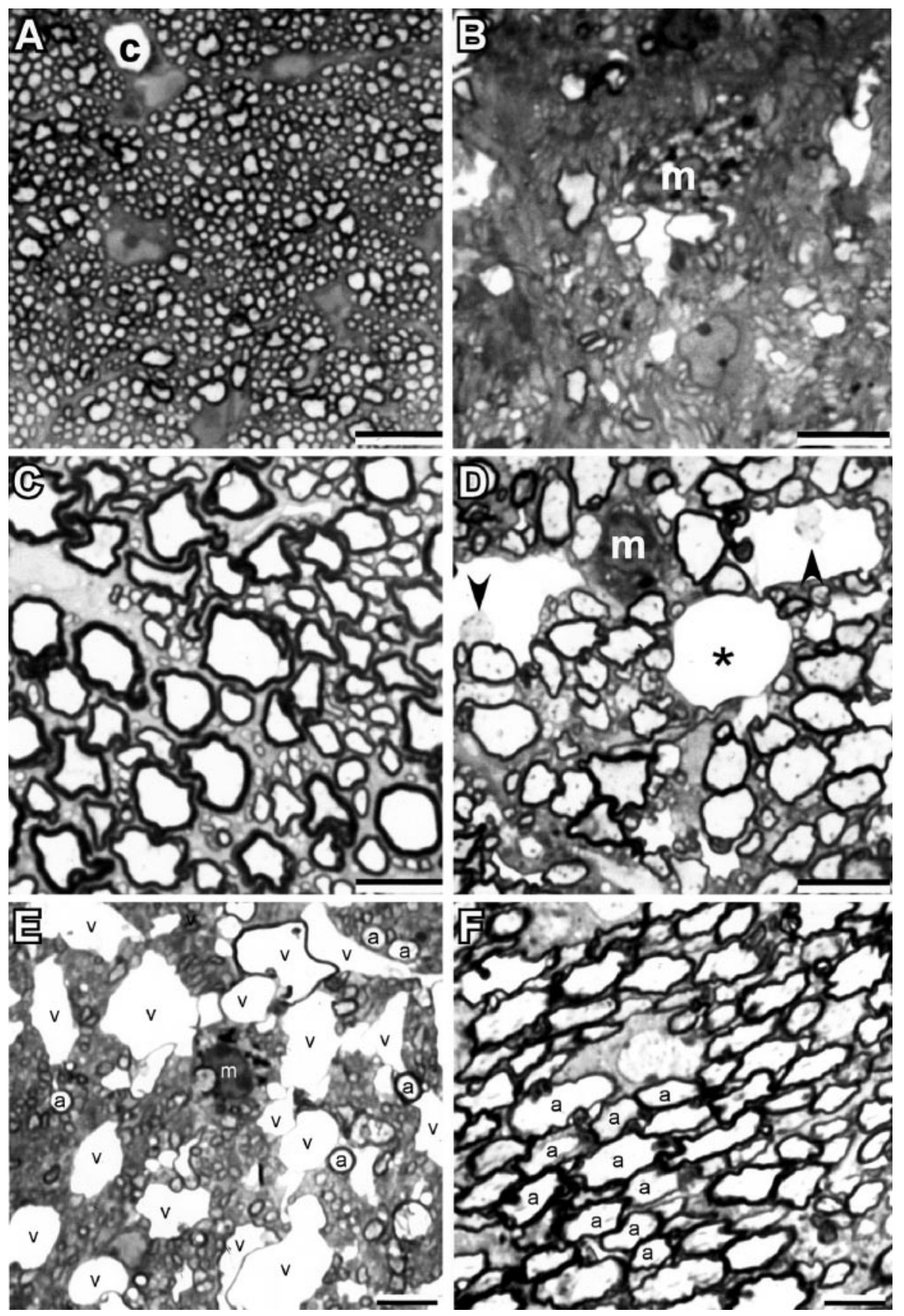

Figure 7. Variable involvement of myelinated axons in $\mathrm{C} \times 32 / C \times 47 \mathrm{dKO}$ CNS. Photomicrographs of semithin sections from optic nerve $(A, B)$ and spinal cord ventral funiculus $(C, D)$ of a P31 WT $(A, C)$ and $C \times 32 / 47$ double-null $(B, D)$ mouse. Note the marked loss of myelinated axons in the optic nerve, the thinner myelin sheaths in the ventral funiculus, and the vacuoles in the myelin sheaths of the mutant. Two of these contain axons (arrowheads) and one is empty (asterisk); a capillary (c) is shown for comparison. $m$, Macrophage. E, F, Photomicrographs of the same semithin section from the pons of a P31 dKO. E, A portion of the corticobulbar tract, which contains numerous small myelinated axons; some of the largest ones are labeled (a). Note the large number of vacuolated myelin sheaths, and macrophage containing myelin debris. $F$, A portion of intramedullary trigeminal nerve, which contains many large myelinated axons, some of which are labeled (a). No vacuolated myelin sheaths are present. Scale bars, $10 \mu \mathrm{m}$.

that oligodendrocyte GJIC is very flexible; subject to different restrictions depending on the location and perhaps activity of the cells involved.

Although we cannot provide a mechanistic explanation for the variation in oligodendrocyte GJIC, it is reasonable to speculate that the expression of multiple connexins contributes to it. Supporting this notion, it is now clear that astrocytes express at least three connexins ( $\mathrm{Cx} 43$, Cx30, and Cx26) (Dermietzel et al., 1989; Kunzelmann et al., 1999; Nagy et al., 2001) and show considerable regional variation in their expression (Nagy et al., 1999). Furthermore, the levels of astrocyte-astrocyte gap junctional coupling are highly sensitive to the activation of different signaling pathways (Giaume and McCarthy, 1996) and also highly variable in a regionspecific manner (D’Ambrosio et al., 1998). Thus, the anatomical relationships of oligodendrocytes and astrocytes and their connexin content may provide a molecular basis for the physiological findings.

Myelin deficiency in connexin mutants Current models for the role of $\mathrm{Cx} 32$ in the peripheral demyelination exhibited by CMTX patients (Bergoffen et al., 1993; Balice-Gordon et al., 1998) do not readily explain the central demyelination in the dKO. Myelinating Schwann cells do not make gap junctions with neighboring cells but rather form "reflexive" gap junctions connecting different regions of the same cell (Sandri et al., 1977; Tetzlaff, 1982). The reflexive junctions are located at paranodal membranes and Schmidt-Lanterman incisures, regions retaining cytoplasm that provide continuity between the perinuclear and periaxonal cytoplasm (Scherer et al., 1995). Junctions in these locations could dramatically shorten the distance for diffusion of nutrients or signals within myelinating Schwann cells. At least theoretically, oligodendrocytes might benefit from reflexive gap junctions between the wraps of myelin in a manner similar to Schwann cells. However, the existence of reflexive junctions in oligodendrocytes has not been clearly established. In any case, neither $\mathrm{Cx} 47$ nor $\mathrm{Cx} 32$ (but see Li et al., 1997) appear to be concentrated at paranodes. Thus, it seems more complex. Dyes injected into astrocytes transferred to astrocytes and oligodendrocytes, but the same dyes injected into oligodendrocytes were restricted to the injected cell. A different pattern was reported in rat spinal cord slices (Pastor et al., 1998), in which dye injected into oligodendrocytes was sometimes observed to move into adjacent oligodendrocytes but never astrocytes. In the same study, white-matter oligodendrocytes displayed no dye transfer whatsoever. Taken at face value, these studies indicate likely that the loss of intercellular (oligodendrocyte-astrocyte) coupling, rather than reflexive coupling, underlies the severe CNS demyelination observed in the dKOs.

The pathologies associated with the $\mathrm{dKO}$ display a unique combination of features not seen together in other myelin-related gene mutants. First, although thinning of the myelin sheaths and axonal loss are found in many myelin-related gene mutants, the 
extensive vacuolation characteristic of the $\mathrm{dKO}$ is a rare finding. Second, apoptotic oligodendrocyte death was clearly evident in the connexin $\mathrm{dKO}$ but is not invariably seen in severe inherited dysmyelination. It is described in some Plp mutations, but it is not prominent in shiverer mice, both of which have severe dysmyelination (Gow et al., 1998; Grinspan et al., 1998). In addition, cell death in the $P l p$ point mutants jimpy, msd, and $m d$ result from a toxic gain-of-function, because PLP null mutants (for review, see Scherer, 1997) display neither oligodendrocyte death nor severe hypomyelination. Thus, the connexin $\mathrm{dKO}$ is the first loss-of-function mutant in which oligodendrocyte cell death is prominent. It remains to be determined whether oligodendrocyte loss is the cause or the effect of the demyelination and whether oligodendrocyte precursor populations are affected.

Another striking feature of the $\mathrm{dKO}$ pathology is its pronounced regionality. We observed severe disruption of fibers in the pons and optic nerve but relatively mild disruption of corticospinal fibers and trigeminal nerve. Local differences in severity have not been reported in other animal models of CNS demyelination. Regional differences have been noted in Plp1 (Griffiths et al., 1998) and Cnp1 (Lappe-Siefke et al., 2003) knock-outs, but those animals present an axonal pathology unaccompanied by oligodendrocyte cell death or demyelination. Hypomyelination and axonal loss in the dKO did not preferentially affect large fibers over small, nor were longer myelinated axons more affected than shorter ones. In most inherited demyelinating neuropathies, including Cx32-null mice, there is a predilection for large myelinated axons, with superimposed distal axonal loss (Martini, 2000; Kleopa and Scherer, 2002). Similarly, a length dependence has been observed in multiple sclerosis and some forms of Pelizaeus-Merzbacher disease, the human central demyelinating disorders for which most data are available (Garbern et al., 2002; Wujek et al., 2002).

These observations raise the issue of why some fibers are affected but others are spared. In this regard, it is provocative that knock-outs in Kir4.1, an inwardly rectifying $\mathrm{K}^{+}$channel expressed primarily in oligodendrocytes (Neusch et al., 2001), display hypomyelination and vacuolation in the spinal cord, as in the connexin $\mathrm{dKO}$. One proposed function for glial Kir channels is to provide part of a pathway for the absorption and removal of extracellular $\mathrm{K}^{+}$released during neuronal activity (Kofuji et al., 2000 ), which in a general sense, is the same function proposed many years ago for glial gap junctions (Orkand et al., 1966). It was suggested that the strongly negative resting potential and relatively high permeability to $\mathrm{K}^{+}$typical of astrocytes could result in a net uptake of $\mathrm{K}^{+}$when the extracellular concentration was high (i.e., after extensive neuronal activity). Gap junctions could facilitate siphoning the absorbed $\mathrm{K}^{+}$into available sinks, such as local capillaries or, in the case of the retina, the vitreous body (Zahs and Newman, 1997), by providing a pathway for lateral diffusion and dispersion. The "spatial buffer theory," as proposed, involved only a network of highly coupled astrocytes. However, inclusion of oligodendrocytes in the astrocyte network might improve its function as a spatial buffer for $\mathrm{K}^{+}$. If so we speculate than the region-specific differences in demyelination observed in the $\mathrm{dKO}$ might reflect the metabolic load of the fiber (i.e., its overall level of activity). Thus, we are currently testing whether local pharmacologic suppression of axonal activity in the $\mathrm{dKO}$ might lead to the sparing of specific fibers. Finally, it may be of interest to determine whether the activities or distributions of connexins are affected in demyelinating diseases such as multiple sclerosis, and thus possibly contribute to the pathogenesis.

\section{References}

Altevogt BM, Kleopa KA, Postma FR, Scherer SS, Paul DL (2002) Connexin29 is uniquely distributed within myelinating glial cells of the central and peripheral nervous systems. J Neurosci 22:6458-6470. 

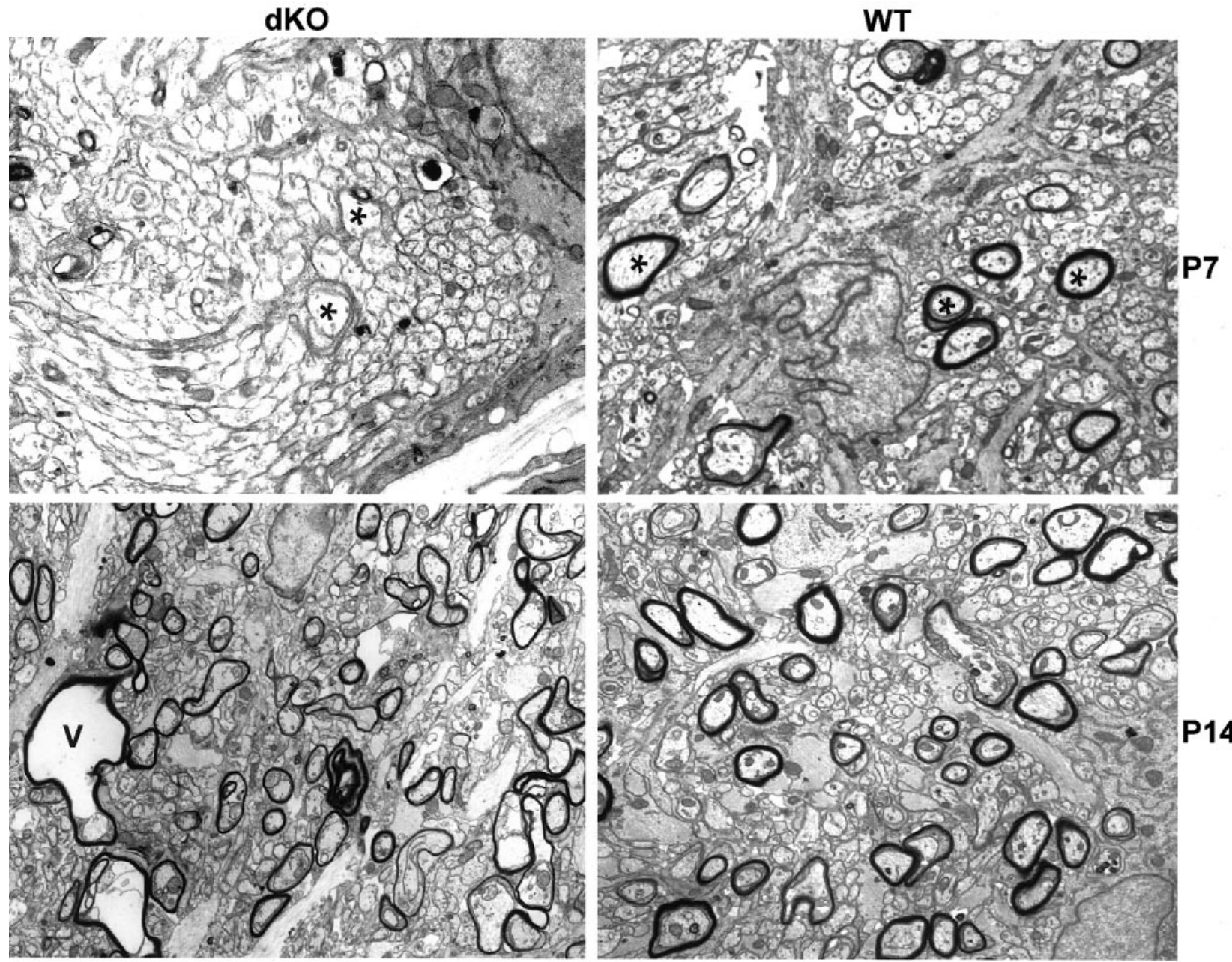

P14
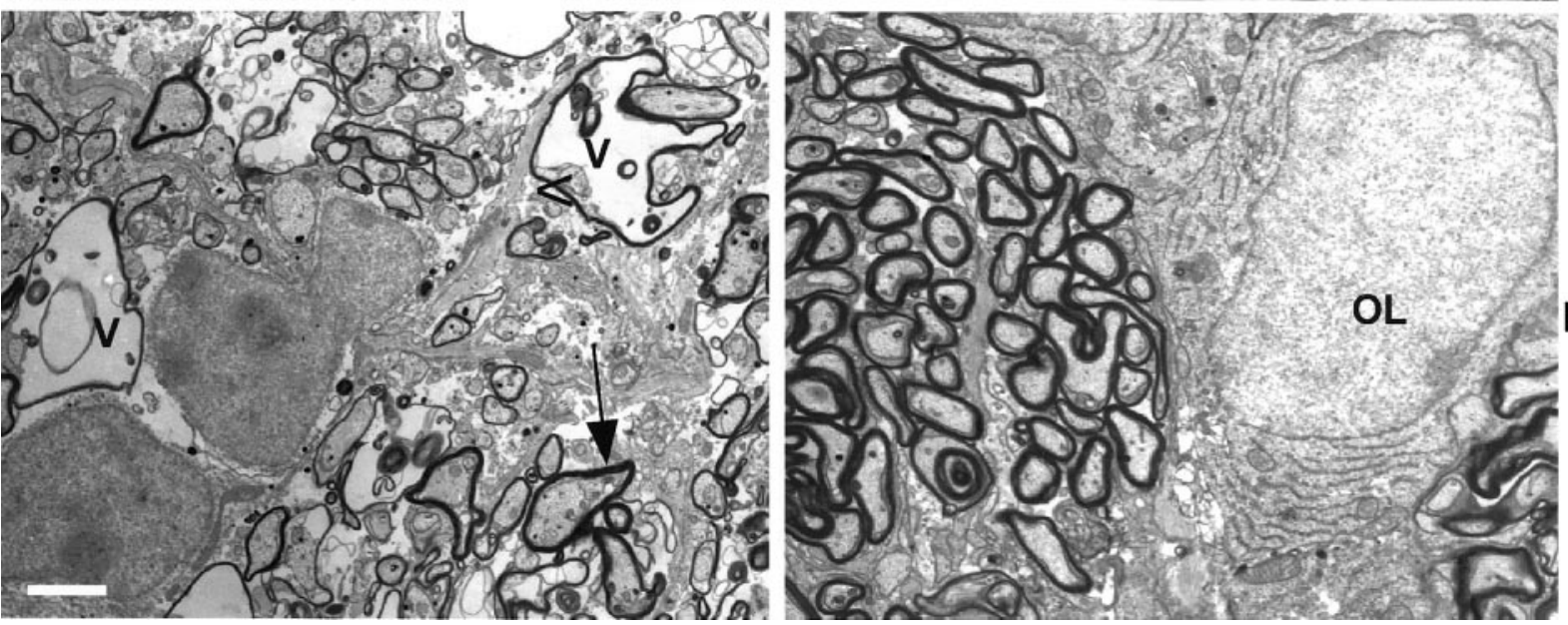

Figure 9. Myelin development in WT and dK0 optic nerve. At P7, a transverse section through optic nerve shows myelin sheaths surrounding large-diameter axons (asterisk) in WT but not in dK0, indicating a delay in myelination. At P14, more axons are myelinated in WT optic nerves; myelin sheaths can also be seen in dK0 optic nerves, but even at this early stage myelin abnormalities such as vacuolation (v) are present. At P21, most axons are surrounded by well formed myelin sheaths in the WT; in contrast dK0 optic nerves at this stage show a rapid progression of the pathology, with thin myelin sheaths, pronounced vacuolation, and oligodendrocyte cytoplasm inclusions between the axons and the myelin sheath (arrow). 0L, 0ligodendrocyte nucleus. Scale bar, $2 \mu \mathrm{m}$.

Balice-Gordon RJ, Bone LJ, Scherer SS (1998) Functional gap junctions in the Schwann cell myelin sheath. J Cell Biol 142:1095-1104.

Bao ZZ, Cepko CL (1997) The expression and function of Notch pathway genes in the developing rat eye. J Neurosci 17:1425-1434.

Bergoffen J, Scherer SS, Wang S, Scott MO, Bone LJ, Paul DL, Chen K, Lensch

MW, Chance PF, Fischbeck KH (1993) Connexin mutations in X-linked

Charcot-Marie-Tooth disease. Science 262:2039-2042.

Bhat RV, Axt KJ, Fosnaugh JS, Smith KJ, Johnson KA, Hill DE, Kinzler KW,
Baraban JM (1996) Expression of the APC tumor suppressor protein in oligodendroglia. Glia 17:169-174.

Butt AM, Ransom BR (1989) Visualization of oligodendrocytes and astrocytes in the intact rat optic nerve by intracellular injection of Lucifer yellow and horseradish peroxidase. Glia 2:470-475.

D’Ambrosio R, Wenzel J, Schwartzkroin PA, McKhann GM, Janigro D (1998) Functional specialization and topographic segregation of hippocampal astrocytes. J Neurosci 18:4425-4438. 
Debus E, Weber K, Osborn M (1983) Monoclonal antibodies specific for glial fibrillary acidic (GFA) protein and for each of the neurofilament triplet polypeptides. Differentiation 25:193-203.

Dermietzel R, Traub O, Hwang TK, Beyer E, Bennett MVL, Spray DC, Willecke K (1989) Differential expression of three gap junction proteins in developing and mature brain tissue. Proc Natl Acad Sci USA 86:10148-10152.

Dermietzel R, Farooq M, Kessler JA, Althaus H, Hertzberg EL, Spray DC (1997) Oligodendrocytes express gap junction proteins connexin32 and connexin45. Glia 20:101-114.

Devaux J, Gola M, Jacquet G, Crest M (2002) Effects of $\mathrm{K}^{+}$channel blockers on developing rat myelinated CNS axons: identification of four types of $\mathrm{K}^{+}$channels. J Neurophysiol 87:1376-1385.

Evans WH, Martin PE (2002) Gap junctions: structure and function. Mol Membr Biol 19:121-136.

Fort P, Marty L, Piechaczyk M, el Sabrouty S, Dani C, Jeanteur P, Blanchard JM (1985) Various rat adult tissues express only one major mRNA species from the glyceraldehyde-3-phosphate-dehydrogenase multigenic family. Nucleic Acids Res 13:1431-1442.

Garbern JY, Yool DA, Moore GJ, Wilds IB, Faulk MW, Klugmann M, Nave KA, Sistermans EA, Van Der Knaap MS, Bird TD, Shy ME, Kamholz JA, Griffiths IR (2002) Patients lacking the major CNS myelin protein, proteolipid protein 1, develop length-dependent axonal degeneration in the absence of demyelination and inflammation. Brain 125:551-561.

Giaume C, McCarthy KD (1996) Control of gap-junctional communication in astrocytic networks. Trends Neurosci 19:319-325.

Gow A, Southwood CM, Lazzarini RA (1998) Disrupted proteolipid protein trafficking results in oligodendrocyte apoptosis in an animal model of Pelizaeus-Merzbacher disease. J Cell Biol 140:925-934.

Griffiths I, Klugmann M, Anderson T, Yool D, Thomson C, Schwab MH, Schneider A, Zimmermann F, McCulloch M, Nadon N, Nave KA (1998) Axonal swellings and degeneration in mice lacking the major proteolipid of myelin 3. Science 280:1610-1613.

Grinspan JB, Coulalaglou M, Beesley JS, Carpio DF, Scherer SS (1998) Maturation-dependent apoptotic cell death of oligodendrocytes in myelin-deficient rats. J Neurosci Res 54:623-634.

Hertzberg E (1984) A detergent-independent procedure for the isolation of gap junctions from rat liver. J Biol Chem 259:9936-9943.

Jiang JX, White TW, Goodenough DA, Paul DL (1994) Molecular cloning and functional characterization of chick lens fiber connexin45.6. Mol Biol Cell 5:363-373.

Kettenmann H, Orkand RK, Schachner M (1983) Coupling among identified cells in mammalian nervous system cultures. J Neurosci 3:506-516.

Kleopa KA, Scherer SS (2002) Inherited neuropathies. Neurol Clin 20:679-709.

Kofuji P, Ceelen P, Zahs KR, Surbeck LW, Lester HA, Newman EA (2000) Genetic inactivation of an inwardly rectifying potassium channel (Kir4.1 subunit) in mice: phenotypic impact in retina. J Neurosci 20:5733-5740.

Kruger O, Plum A, Kim J, Winterhager E, Maxeiner S, Hallas G, Kirchhoff S, Traub O, Lamers WH, Willecke K (2000) Defective vascular development in connexin 45-deficient mice. Development 127:4179-4193.

Kumai M, Nishii K, Nakamura K, Takeda N, Suzuki M, Shibata Y (2000) Loss of connexin 45 causes a cushion defect in early cardiogenesis. Development 127:3501-3512.

Kunzelmann P, Blumcke I, Traub O, Dermietzel R, Willecke K (1997) Coexpression of connexin 45 and -32 in oligodendrocytes of rat brain. J Neurocytol 26:17-22.

Kunzelmann P, Schroder W, Traub O, Steinhauser C, Dermietzel R, Willecke $\mathrm{K}$ (1999) Late onset and increasing expression of the gap junction protein connexin 30 in adult murine brain and long-term cultured astrocytes. Glia 25:111-119.

Lappe-Siefke C, Goebbels S, Gravel M, Nicksch E, Lee J, Braun PE, Griffiths IR, Nave KA (2003) Disruption of Cnp1 uncouples oligodendroglial functions in axonal support and myelination. Nat Genet 33:366-374.

Levin M (2002) Isolation and community: a review of the role of gapjunctional communication in embryonic patterning. J Membr Biol 185:177-192.

Li J, Hertzberg EL, Nagy JI (1997) Connexin32 in oligodendrocytes and association with myelinated fibers in mouse and rat brain. J Comp Neurol 379:571-591.
Li X, Lynn BD, Olson C, Meier C, Davidson KG, Yasumura T, Rash JE, Nagy JI (2002) Connexin29 expression, immunocytochemistry and freezefracture replica immunogold labelling (FRIL) in sciatic nerve. Eur J Neurosci 16:795-806.

Martini R (2000) Animal models for inherited peripheral neuropathies. J Neurosci Res 61:244-250.

Massa PT, Mugnaini E (1982) Cell junctions and intramembrane particles of astrocytes and oligodendrocytes: a freeze-fracture study. Neuroscience 7:523-538.

Massa PT, Szuchet S, Mugnaini E (1984) Cell-cell interactions of isolated and cultured oligodendrocytes: formation of linear occluding junctions and expression of peculiar intramembrane particles. J Neurosci 4:3128-3139.

Matheson DF (1970) Some quantitative aspects of myelination of the optic nerve in rat. Brain Res 24:257-269.

Milner RJ, Lai C, Nave KA, Lenoir D, Ogata J, Sutcliffe JG (1985) Nucleotide sequences of two mRNAs for rat brain myelin proteolipid protein. Cell 42:931-939.

Mullen RJ, Buck CR, Smith AM (1992) NeuN, a neuronal specific nuclear protein in vertebrates. Development 116:201-211.

Nagy JI, Ochalski PAY, Li J, Hertzberg EL (1997) Evidence for the colocalization of another connexin with connexin-43 at astrocytic gap junctions in rat brain. Neuroscience 78:533-548.

Nagy JI, Patel D, Ochalski PA, Stelmack GL (1999) Connexin30 in rodent, cat and human brain: selective expression in gray matter astrocytes, colocalization with connexin 43 at gap junctions and late developmental appearance. Neuroscience 88:447-468.

Nagy JI, Li X, Rempel J, Stelmack G, Patel D, Staines WA, Yasumura T, Rash JE (2001) Connexin26 in adult rodent central nervous system: demonstration at astrocytic gap junctions and colocalization with connexin 30 and connexin43. J Comp Neurol 441:302-323.

Nelles E, Bützler C, Jung D, Temme A, Gabriel H-D, Dahl U, Traub O, Stümpel F, Jungermann K, Zielasek J, Toyka KV, Dermietzel R, Willecke K (1996) Defective propagation of signals generated by sympathetic nerve stimulation in the liver of connexin32-deficient mice. Proc Natl Acad Sci USA 93:9565-9570.

Neusch C, Rozengurt N, Jacobs RE, Lester HA, Kofuji P (2001) Kir4.1 potassium channel subunit is crucial for oligodendrocyte development and in vivo myelination. J Neurosci 21:5429-5438.

Orkand RK, Nicholls JG, Kuffler SW (1966) Effect of nerve impulses on the membrane potential of glial cells in the central nervous system of amphibia. J Neurophysiol 29:788-806.

Pastor A, Kremer M, Moller T, Kettenmann H, Dermietzel R (1998) Dye coupling between spinal cord oligodendrocytes: differences in coupling efficiency between gray and white matter. Glia 24:108-120.

Paul DL (1986) Molecular cloning of cDNA for rat liver gap junction protein. J Cell Biol 103:123-134.

Rash JE, Dillman RK, Bilhartz BL, Duffy HS, Whalen LR, Yasumura T (1996) Mixed synapses discovered and mapped throughout mammalian spinal cord. Proc Natl Acad Sci USA 93:4235-4239.

Rash JE, Duffy HS, Dudek FE, Bilhartz BL, Whalen LR, Yasumura T (1997) Grid-mapped freeze-fracture analysis of gap junctions in gray and white matter of adult rat central nervous system, with evidence for a "panglial syncytium" that is not coupled to neurons. J Comp Neurol 388: 265-292.

Rash JE, Yasumura T, Dudek FE, Nagy JI (2001) Cell-specific expression of connexins and evidence of restricted gap junctional coupling between glial cells and between neurons. J Neurosci 21:1983-2000.

Robinson SR, Hampson ECGM, Munro MN, Vaney DI (1993) Unidirectional coupling of gap junctions between neuroglia. Science 262: 1072-1074.

Sandri C, Van Buren JM, Akert K (1977) Membrane morphology of the vertebrate nervous system. A study with freeze-etch technique. Prog Brain Res 46:1-384.

Scherer SS (1997) Molecular genetics of demyelination: new wrinkles on an old membrane. Neuron 18:13-16.

Scherer SS, Deschenes SM, Xu YT, Grinspan JB, Fischbeck KH, Paul DL (1995) Connexin32 is a myelin-related protein in the PNS and CNS. J Neurosci 15:8281-8294. 
Scherer SS, Xu YT, Nelles E, Fischbeck K, Willecke K, Bone LJ (1998) Connexin32-null mice develop demyelinating peripheral neuropathy. Glia 24:8-20.

Tennekoon GI, Cohen SR, Price DL, McKhann GM (1977) Myelinogenesisin optic nerve: a morphological, autoradiographic, and biochemical analysis. J Cell Biol 72:604-616.

Tetzlaff W (1982) Tight junction contact events and temporary gap junctions in the sciatic nerve fibres of the chicken during Wallerian degeneration and subsequent regeneration. J Neurocytol 11:839-858.

Teubner B, Odermatt B, Guldenagel M, Sohl G, Degen J, Bukauskas F, Kronengold J, Verselis VK, Jung YT, Kozak CA, Schilling K, Willecke K (2001) Functional expression of the new gap junction gene connexin 47 transcribed in mouse brain and spinal cord neurons. J Neurosci 21: $1117-1126$.

Venance L, Cordier J, Monge M, Zalc B, Glowinski J, Giaume C (1995)
Homotypic and heterotypic coupling mediated by gap junctions during glial cell differentiation in vitro. Eur J Neurosci 7:451-461.

Waxman SG, Black JA (1984) Freeze-fracture ultrastructure of the perinodal astrocyte and associated glial junctions. Brain Res 308:77-87.

White TW, Paul DL (1999) Genetic diseases and gene knockouts reveal diverse connexin functions. Annu Rev Physiol 61:283-310.

White TW, Goodenough DA, Paul DL (1998) Targeted ablation of connexin50 in mice results in microphthalmia and zonular pulverulent cataracts. J Cell Biol 143:815-825.

Wujek JR, Bjartmar C, Richer E, Ransohoff RM, Yu M, Tuohy VK, Trapp BD (2002) Axon loss in the spinal cord determines permanent neurological disability in an animal model of multiple sclerosis. J Neuropathol Exp Neurol 61:23-32.

Zahs KR, Newman EA (1997) Asymmetric gap junctional coupling between glial cells in the rat retina. Glia 20:10-22. 